\title{
Correction to: Pretty crowds are happy crowds: the influence of attractiveness on mood perception
}

\author{
Alica Mertens $^{1}$ (D) $\cdot$ Johanna Hepp ${ }^{2} \cdot$ Andreas Voss $^{1} \cdot$ Amelie Hische $^{1}$
}

Published online: 6 June 2021

(c) The Author(s) 2021

\section{Correction to: Psychological Research https://doi.org/10.1007/s00426-020-01360-x}

The article "Pretty crowds are happy crowds: the influence of attractiveness on mood perception", written by Alica Mertens, Johanna Hepp, Andreas Voss and Amelie Hische, was originally published electronically on the publisher's internet portal on 25 May 2020 without open access. With the author(s)' decision to opt for Open Choice the copyright of the article changed on 25 May 2021 to $($ ) The Author(s) 2020 and the article is forthwith distributed under a Creative Commons Attribution 4.0 International License, which permits use, sharing, adaptation, distribution and reproduction in any medium or format, as long as you give appropriate credit to the original author(s) and the source, provide a link to the Creative Commons licence, and indicate if changes were made. The images or other third party material in this article are included in the article's Creative Commons licence, unless indicated otherwise in a credit line to the material. If material is not included in the article's Creative Commons licence and your intended use is not permitted by statutory regulation or exceeds the permitted use, you will need to obtain permission directly from the copyright holder. To view a copy of this licence, visit http://creativecommons.org/licenses/by/4.0.

Open Access funding enabled and organized by Projekt DEAL.

The original article has been updated.

The original article can be found online at https://doi.org/10.1007/ s00426-020-01360-x.

Alica Mertens

alica.mertens@psychologie.uni-heidelberg.de

1 Institute of Psychology, Heidelberg University, Hauptstr. 47-51, 69117 Heidelberg, Germany

2 Department of Psychosomatic Medicine, Central Institute of Mental Health, Medical Faculty Mannheim/Heidelberg University, Mannheim, Germany
Publisher's Note Springer Nature remains neutral with regard to jurisdictional claims in published maps and institutional affiliations. 